\title{
Russian Philosophy on the Value of an Individual*
}

\author{
Igor Grebeshev \\ Department History of Philosophy \\ Peoples' Friendship University of Russia (RUDN University) \\ 6 Miklukho-Maklaya Street, Moscow, 117198, Russian Federation \\ E-mail: igor.grebeshev@yandex.ru
}

\begin{abstract}
The author of the article represents the philosophy's personalist branch as an integral living process of Russian philosophical thought development in the late $19^{\text {th }}$ early $20^{\text {th }}$ centuries, rich with interaction, debate and discussion. The author shows, how the reception of the European personalist tradition was accompanied by a development of the Russian original concepts, a search for the new grounds, justifying the value of an individual, including, but not limiting to the frameworks of "Neo-Leibnizianism" (L. Lopatin, A. Kozlov, S. Alexeev), Neo-Kantianism (S. Hessen), personalist philosophy of education (S. Hessen and V. Zenkovsky), metaphysics of unitotality (Vl. Solovyov, S. Frank, L. Karsavin), G. Fedotov's philosophy of culture and N. Berdyaev's existential personalism. Each of the aforementioned Russian thinkers attempted to solve with their own distinct way the problem of metaphysical "justification" of the value of an individual. The author of the article identifies the existential vector of the Russian personalism.
\end{abstract}

Keywords-unitotality; personalism; value of an individual; philosophy of education; pedagogical personalism; existentiality

\section{INTRODUCTION}

N. Berdyaev noted already in 1931, that "we are entering the era of civilization, denying the value of an individual" [1. P. 498]. However, the problem of the value of an individual is one of the iconic and the most fundamental problems in the history of the Russian and European philosophies. The said problem is not losing but taking on a special urgency and poignancy in today's global civilization. Mankind's colossal scientific and technological achievements open up entirely new possibilities for human activities in nature and history and, therefore, radically expand the limits of human freedom. Yet, in line with these achievements, people face new challenges and threats to their freedom, unprecedented in the previous historical epochs. "Information society" is not "a leap to the kingdom of freedom", or "the realized utopia", as N. Berdyaev would have put it. Traditional technologies of ideological and social enslavement of an individual would seem completely archaic in comparison to the latest methods of manipulating mass and individual consciousness. "A human is in danger", - exclaimed the philosopher in his 1933 "Man and Machine".

We should give credit to philosophy: for at least the last

*This publication was supported by the Ministry of Education and Science of the Russian federation (the Agreement number 02.A03.21.0008). Peoples' Friendship University of Russia (RUDN University). two centuries the most profound thinkers and philosophical movements warned about the illusory nature of the belief in the automaticity of any civilization's progress, solving all the problems and providing mankind with a "bright future". At the same time, philosophers considered the task of philosophical justification of an individual's sovereignty, outside of which no genuine progress is viable. With a special urgency and consistency, this task was being defined and solved in European and Russian personalism.

\section{Personalist ThOUGHT IN THE RUSSIAN PHILOSOPHY}

It is fair to say that for the Russian metaphysical philosophers of the $20^{\text {th }}$ century, the topic of identity and its historical destiny was of fundamental importance. What had they written on "slavery and freedom of human" in the context of modern civilization causes not only a historicalphilosophical interest. We do not doubt, e.g., the intellectual, and, to a large extent, the predictive value of Berdyaev's apology of an individual's existential experience, creatively confronting all the new forms of "objectification", threatening the very foundation of human identity as a rational and free being. No less important is a stance taken by $\mathrm{G}$. Fedotov on the personalist character of the cultural tradition, that "the tragedy of culture", destruction of its axiological bases in a technologically organized civilized space inevitably turns to the most profound identity crisis.

Personalist ideas were widely represented in the different branches of the Russian religious metaphysics. Reception of the basic principles of the European personalist tradition was accompanied by the development of the own original concepts, new ways of justifying the Christian metaphysics of an individual. E.g., although the Russian "NeoLeibnizianism" is much obliged to Leibniz' and his students' monadology. It is doubtless that the ideas of the outstanding German personalist found a new life in the works of $\mathrm{L}$. Lopatin, A. Kozlov, S. Alexeev, N. Lossky. This also applies to the personalist experience of the Russian NeoKantianism. The brightest example is S. Hessen's personalist philosophy of education. The most impressive personalist systems in line with the Russian metaphysics of unitotality were developed by S. Frank and L. Karsavin. Both of the Russian thinkers had always stressed the relation of their beliefs with the European Platonism and, in the first place, with the religious philosophy of Nicholas of Cusa. However, their own personalist teachings show vital distinction and 
know no equals in the Platonic tradition [2]. One may find original approaches to the personalism in the works of the other Russian thinkers, close to the metaphysics of unitotality, e.g., S. Bulgakov and P. Florensky. A classic example of consistent Christian personalism is V. Zenksovsky's religious-philosophical anthropology. The philosophical effectiveness of personalistic principles found its expression, in particular, in the development of the new areas of philosophical knowledge on their bases, including: philosophical anthropology and philosophy of religion (S. Frank), philosophical pedagogy and philosophy of education (V. Zenkovsky, S. Hessen), philosophy of art (L. Karsavin, G. Fedotov).

Personalist principles have traditionally played an integral role in the Russian philosophical pedagogy: Vl. Odoyevsky's "the child individual", education as an "integral dispensation of the spirit" (I. Kireevsky), N. Pirogov's ideal of "living Weltanschauung", the philosophical-pedagogical meaning of P. Yurkevich's on "the role of the heart in the human's spiritual life" etc. In the $20^{\text {th }}$ century, pedagogical personalism finds a consistent philosophical nature in the systems by V. Zenkovsky and S. Hessen. Comparative analysis of V. Zenkovsky's and S. Hessen's concepts of education allows to determine the specificity of personalist views of the Russian thinkers; to identify the methodological significance of philosophical psychology in V. Zenkovsky's pedagogical concept; and to conclude that S. Hessen's theory of education is unprecedented, concerning its methodology and insights, having no counterparts in the history of European Kantianism and is close in its actual aspects to the humanitarian direction in the modern philosophy of education (primarily to the phenomenological rendition of "pedagogical anthropology" and to the analytical philosophy of education).

\section{PECUlarity OF NiKOlai BerdyaEV'S AND GeORGE FEDOTOV'S PERSONALISM}

N. Berdyaev and G. Fedotov represent another pole of the Russian religious philosophy, almost opposing the tradition of the metaphysics of unitotality. N. Berdyaev is a consistent anti-Platonist, who saw a kind of philosophical "crime" against an individual and freedom in any justification of the absolute values of the ideal principles of existence. While the idea of ontological freedom, which is connected to individual freedom and in which the latter is rooted, plays a core role in Berdyaev's personalism, Fedotov was inclined to the fundamental personalist nature of culture, and in this case, it is possible to even speak of a certain personalist "cultural centrism". Only by creating the world of culture and living in it, an individual meets his metaphysical destiny, achieving the fullness of life and freedom. The cultural crisis is always and everywhere is a symptom of an identity crisis.

These assumptions of the personalist historiosophy of the Russian thinkers predetermined to a significant extent the peculiarity of their visions of the meaning of various historical events and epochs. N. Berdyaev seeks and surely finds in history various forms of "objectification", leading to the enslavement of an individual one way or another. In almost every book and article, the philosopher unmasks much hated "objectification", whatever social, cultural and ideological guises it takes. There's no denying that Berdyaev's criticism of "servile" consciousness was exceptionally profound. This philosophical criticism in itself identifies the historical-philosophical value of the thinker's stance. He actually had a reason to call himself a "philosopher of freedom": he knew no taboos and ideological fetishes. Slavery (and, above all, spiritual slavery) of individuals was unacceptable for him, no matter what historical forms it chose: ancient or modern, religious or moral, bourgeois or totalitarian, or Western or Russian. In Berdyaev's existential personalism, history itself acquires an existential nature. Despite all the failures and defeats, an existential individual realizes himself in the historical time, implementing creativity in the experience of a personal creative freedom, tearing in "transcendence", though only for a brief moment of "existential time", the slave "shackles of existence".

However, G. Fedotov's personalism also shows distinct features of existentialism. The meaning of history, according to him, is found in the history of culture, while the latter may only be comprehended in its existential dimension. Already in his early works on St. Augustine, Abelard, and Dante, G. Fedotov sought for a key in personal, existential experience of the great thinkers of the past to comprehend the era and cultural traditions. In his work "Is and Will Be" he in a no metaphorical way likens Russia to a "living person", preserving to the last moment the freedom of choice of the own historical fate. In "The Saints of Old Rus" the thinker undergoes and depicts "the tragedy of the Old Rus holiness" as a deeply personal tragedy associated with the attainment of spiritual freedom and its irreparable loss [3]. In his dispute with the artistic and philosophical modernism, G. Fedotov, in accordance with the principles of existential personalism, defended the idea of an individual identity of a human being, absolute priority of the personal principles in history and culture ("Ecce homo", "In Defense of Ethics", "Christian Tragedy" etc.). To a large extent, this very existential orientation, despite all the marked and quite significant differences, brings closer historiosophical personalism of $\mathrm{N}$. Berdyaev and G. Fedotov. However, such personalist existentialism is the distinctive feature of the whole new Russian metaphysics. One way or another, it manifests itself just as in S. Frank's and V. Zenkovsky's anthropology, so in L. Karsavin's teaching on personality. Russian thinkers, each in his own way, dealt with the problem of metaphysical "justification" of an individual's dignity; their works are an important and integral part of the history of the $20^{\text {th }}$-century personalist philosophy.

Comparing historical-philosophical standpoints of the Russian metaphysicians, one should note that their assessments of various ideas and philosophical fields didn't have pivotal differences. The thinkers are brought together, in particular, by a critical attitude to radical forms of rationalism and irrationalism alike; a strong rejection of philosophical and ideological doctrines neglecting the metaphysical tradition (positivism, Marxism, etc.); and, most importantly, a consistent criticism of intelligent setups, that 
somehow "deny" and "humiliate" metaphysical dignity of a man, of an individual. In other words, the Russian metaphysicians have, firstly, personalism of their philosophical views in common. However, the same circumstance, to a great extent, is linked to the uniqueness of their historical and philosophical positions.

For example, Berdyaev's personalism is focused on discovery in the history of thought of the fields and positions "close" or, on the contrary, "alien" to the idea of "groundless", absolute freedom. If we are to use well-known Popper's cliché, we may say that the "history of philosophy", according to Berdyaev, is a passionate and, in many ways, wonderful story about absolute freedom, its friends and enemies. G. Fedotov, as well as L. Karsavin, was always interested in the cultural meaning and productivity of the philosophical aspirations of the thinkers of the past and present. This version of personalism implies the consideration of philosophical doctrines not so much in terms of their speculative value (not in terms of "history of ideas") but mainly in the historical and cultural context, with the context being historiosophical, extremely widely defined [4. P. 361]. There's no doubt that the historical-philosophical value and vitality of the personalist ideas of the Russian thinkers will continue to serve as the basis for a deep and permanent interest to the history of the Russian philosophy.

\section{CONCLUSION}

The abyss of totalitarian ideology rendered the development of personalism in the Russian philosophy impossible. V.V. Serbinenko noted in this regard that "there were differences, and also fundamental, in social ideals among the Russian thinkers, but there were simply no direct or indirect votaries of totalitarianism among the major figures of the Russian culture". Moreover, many of them had warned at the beginning of the $20^{\text {th }}$ century of the real threat of totalitarian ideology approval, including those found in the West, of a deep crisis of Euro-Atlantic democracy (cf. N. Berdyaev, S. Frank, G. Fedotov, I. Ilyin and many others) [5. P. 307, 304]. At the end of the last century, A. Zinovyev spoke about "totalitarian democracy" [6. P. 324], "which essential features are yet to be explored, but which has already triumphed" [7. P. 318].

\section{REFERENCES}

[1] N. Berdyaev, Spiritual State of the Modern World // Philosophy of Creativity, Culture and Art: in 2 Vols. Vol. 1. M.: Iskusstvom 1994. P. 485-499.

[2] Chistyakova O.V. Byzantium - Russ - Russia. Philosophical and Anthropological Traditions. Textbook. Kuban State University Press. Krasnodar-Moscow. 2005

[3] Chistyakova O.V. The Problem of a Human in Eastern Orthodox Patristic. Monograph. North Caucasian Scientific Center of the Higher School Press. Rostov-on-Don, 1999.

[4] Grebeshev I.V. Metaphysics of Personality in the Russian Philosophy of the $20^{\text {th }}$ Century. M.: RUDN, 2008.

[5] Serbinenko V.V. The Russian Idea and Prospect for Democracy in Russia // Metaphysics of Socio-Cultural Existence in the Experience of the Russian Philosophy. Stavropol, SevKavGTU, 2010.
[6] Zinovyev A. Interview with Anthony Fernandez Ortiz // The Phenomenon of Zinovyev. M.: Sovremennye tetradi, 2002.

[7] Nizhnikov S.A. Morality and Ethics in the Context of Spiritual and Intellectual Traditions. M.: INFRA-M, 2014. 